\title{
Purification of the Third Factor of Anthrax Toxin
}

\author{
By H. SMITH AND J. L. STANLEY \\ Microbiological Research Establishment, Porton, Salisbury, Wiltshire
}

(Received 16 February 1962)

\begin{abstract}
SUMMARY
Factor III of anthrax toxin, which increases the lethality of mixtures of factors I and II for mice and decreases their capacity to produce oedema in the skin of rabbits, has been purified. The final preparation showed a single peak in the ultracentrifuge and a single band on paper electrophoresis, but it might still contain more than one serological component. The final preparation was a protein $(\mathrm{N}=15 \cdot 1 \%$ ) containing all the usual amino acids but no carbohydrate, phosphorus, lipid or ash.
\end{abstract}

\section{INTRODUCTION}

Bacillus anthracis produces a specific lethal and oedema-forming toxin which was first recognized in vivo, and then produced in vitro (Smith, Keppie \& Stanley, 1955; Harris-Smith, Smith \& Keppie 1958; Thorne, Molnar \& Strange 1960). At first the toxin appeared to consist only of two components, factor I and factor II, which acted synergistically (Smith et al. 1956; Thorne et al. 1960; Stanley, Sargeant \& Smith 1960; Sargeant, Stanley \& Smith 1960). During the further purification of factor I (Stanley \& Smith 1961) a third component, factor III, was recognized in the following way. The final preparation of factor I was not toxic when injected alone; as expected a mixture of factor I with purified non-toxic factor II evoked oedema in the skin of a rabbit and killed mice. However, the concentration of this mixture which killed mice formed a much larger skin reaction in rabbits than did a comparable dose (based on mouse LD 50 dose) of either crude toxin or a mixture of crude factors I + II. An investigation of this observation led to the demonstration of a factor III, present in crude factor I or II, which $(a)$ increased the lethality of mixtures of factors I and II for mice and decreased their capacity to produce oedema in rabbits; $(b)$ was different serologically from factors I or II; $(c)$ was non-toxic when injected alone; $(d)$ was lethal for mice when mixed with factor II but not with factor I; $(e)$ was present in the anthrax toxin produced in vivo. The present paper describes the purification and properties of factor III.

\section{METHODS}

Crude factor III from toxin produced in vitro. Crude anthrax toxin produced by the method of Thorne et al. (1960) was separated into crude factor I and crude factor II by filtration through sintered glass filters. Factor III was present in the crude factor I (absorbed on glass filters and eluted as described by Stanley \& Smith 1961, except that the volume of saturated $\mathrm{Na}_{2} \mathrm{CO}_{3}$ used to elute the filters was increased to $8 \mathrm{ml}$.) and in the crude factor II (the filtrate). The relative amounts of factor III 
in the eluate from the filters and in the filtrate varied with the particular batch of filters used, but the eluate from a filter always contained more than half the factor III in a volume (about $8 \mathrm{ml}$. from one filter) considerably less than that of the filtrate $(1 \mathrm{l}$. from one filter). Therefore factor III was purified from the filter eluate (crude factor I).

Detection and estimation of factor III. Factor III was present in a solution which was non-toxic when injected alone but which formed a mixture lethal for mice when added to an otherwise non-lethal mixture of purified factor I $(4 \mu \mathrm{g})+$. purified factor II (40 $\mu \mathrm{g}$.; see Stanley \& Smith 1961, table 5). However, it was more convenient (especially with solutions which contained large amounts of factors I and II which affected the mouse test) and less expensive of materials, to fractionate factor III by its reaction in serological diffusion plates which used the system and antiserum ('spore' H 533) described by Sargeant et al. (1960) and Stanley \& Smith (1961). Preliminary fractionations (Stanley \& Smith, 1961) had showed that under these conditions the factor III activities of solutions were associated with their ability to form a precipitation line which was different from that formed by purified factors I and II, and which appeared to be single, although there was some evidence (see later) that it might have been multiple. Fractionation of factor III was followed by comparing the null-points (the first dilution which did not form the factor III line) of different fractions. Finally, the toxicity (in association with factors I and II) for mice of the final preparation of factor III was compared with that of the original crude eluate, to check that the recovery of activity (mouse-toxicity) in the final product was in fact equal to the recovery indicated by the serological titrations (see later).

Purified factors I and II of anthrax toxin were prepared as described by Stanley \& Smith (1961).

Analytical and physico-chemical methods. These were as described by Stanley \& Smith (1961).

Biological tests for lethality in mice and oedema production in rabbits. These were described by Stanley \& Smith (1961).

\section{RESULTS \\ Purification of factor III}

A preliminary fractionation of factor III from crude factor II (i.e. culture filtrate) was described by Stanley \& Smith (1961), and this provided a basis for the first part of the purification of factor III from crude factor I (eluate from the filters).

Chromatography on diethylaminoethyl cellulose (DEAEC). Crude factor I (containing factor III; $320 \mathrm{ml}$., 'protein' $0.06 \%$, null point of factor III line 1/64) was diluted with $0.005 I$ phosphate buffer $(\mathrm{pH} 7 \cdot 4 ; 2880 \mathrm{ml}$.) and applied to a column $(4.5 \mathrm{~cm}$., diam., $10 \mathrm{~cm}$. long) of DEAEC (25 g.) which had been equilibrated with $0.1 I$ phosphate buffer $(\mathrm{pH} 7 \cdot 4)$; the flow rate was about $20 \mathrm{ml} . / \mathrm{min}$. The column was eluted with $0 \cdot 12 I$ phosphate buffer $(\mathrm{pH} 7 \cdot 4 ; 500 \mathrm{ml}$.), $0 \cdot 2 I$ phosphate buffer containing $0.01 I \mathrm{NaCl}(\mathrm{pH} 7 \cdot 4 ; 2.51$ ) and $0.2 I$ phosphate buffer containing $0.2 I \mathrm{NaCl}(\mathrm{pH} 7 \cdot 2 ; 600 \mathrm{ml}$.) in $8 \times 75 \mathrm{ml}$. fractions. The latter buffer eluted the factor III (in the last six fractions, $450 \mathrm{ml}$; ; null point of factor III line $1 / 16$ to $1 / 32$; $0.005 \%$ 'protein') which was contaminated with some factor I (about $5 \%$ of the 'protein' by comparative titration with purified factor I in serological gel-diffusion 
plates). This fraction was concentrated and the contamination with factor $I$ decreased by the following procedure. After dialysis (overnight, $0-2^{\circ}$ ) against

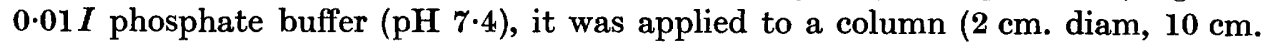
long), of DEAEC (3 g.) which had been equilibrated with $0 \cdot 1 I$ phosphate buffer $(\mathrm{pH} 7 \cdot 4)$; the flow rate was about $8 \mathrm{ml} . / \mathrm{min}$. The column was eluted with $\mathbf{0 . 2 I}$ phosphate buffer containing $0.01 \mathrm{I} \mathrm{NaCl}(\mathrm{pH} 7 \cdot 4 ; 250 \mathrm{ml}$.) followed by $0.2 I$ phosphate buffer containing $0 \cdot 2 I \mathrm{NaCl}$ ( $\mathrm{pH} 7 \cdot 2 ; 10$ fractions of $10 \mathrm{ml}$.). Fractions $3-7$ of the latter buffer contained the factor III ( $50 \mathrm{ml}$.; 'protein' $0.036 \%$, null point of factor III line 1/160). Although contamination with factor I had been decreased (less than $2 \%$ of the 'protein'), examination of the preparation of factor III in the ultracentrifuge showed some smaller and larger molecular material in addition to the main component. The material was then fractionated on hydroxylapatite.

Chromatography on hydroxylapatite. The material (50 ml.; 'protein' $0.036 \%$; null point of factor III line 1/160) was dialysed overnight at $0-2^{\circ}$ against $0 \cdot 1 \mathrm{M}$-potassium phosphate buffer ( $\mathrm{pH} 7 \cdot 0)$ and applied to a column $(2 \mathrm{~cm}$. diam., $10 \mathrm{~cm}$. long) of hydroxylapatite ( $3 \mathrm{~g}$.) which had been equilibrated with $0 \cdot 1 \mathrm{M}$-potassium phosphate buffer ( $\mathrm{pH} \mathrm{7 \cdot 0)}$. A slight positive pressure was used to produce a flow rate of about

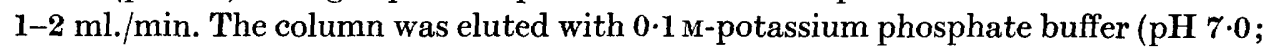
$30 \mathrm{ml}$.) followed by $0 \cdot 4 \mathrm{M}$-potassium phosphate buffer (pH 7.0;50 ml.) in $10 \times 5 \mathrm{ml}$. fractions. Factor III was removed by the second buffer and concentrated in 3 of the later fractions which were bulked and concentrated as described below.

Concentration by precipitation with ammonium sulphate. The preparation of factor III (15 ml., 0.1\% 'protein', null point of factor III line 1/320) was mixed with ammonium sulphate $\left(7 \cdot 5\right.$ g.). After standing overnight $\left(0-2^{\circ}\right)$ the precipitate was collected by centrifugation $\left(12,000 \mathrm{~g} ; 30 \mathrm{~min} . ; 0^{\circ}\right)$, dissolved in $0.05 \mu$ phosphate buffer (1.0 ml.; pH 7.4) and dialysed for $48 \mathrm{hr}$. at $0-2^{\circ}$ against frequent changes of $0 \cdot 05 \mu$ phosphate buffer $(\mathrm{pH} 7 \cdot 4)$. The preparation was stored at $-20^{\circ}$.

Recovery of factor III activity. In the assay by serological precipitation the final solution ( $1.5 \mathrm{ml}$., 'protein' $0.85 \%$, null point of factor III line $1 / 3200$ ) contained $\mathbf{2 5 - 3 0} \%$ of the factor III originally present in the crude eluate $(320 \mathrm{ml}$., 'protein' $0.06 \%$, null point of factor III line $1 / 64$ ). This recovery of factor III activity was also indicated by the following toxicity tests. When added to a mixture of factor I (4 $\mu \mathrm{g}$.) and factor II (40 $\mu \mathrm{g}$.) which alone killed only $10 / 126$ mice, the final preparation of factor III in doses of $0.0005 \mathrm{ml}$. and $0.00025 \mathrm{ml}$. killed $22 / 28$ and 10/20 mice, respectively. Since $1.5 \mathrm{ml}$. of the final preparation came from $320 \mathrm{ml}$. of crude eluate, (about $25 \%$ recovery of activity was indicated) about 0.025 and $0.0125 \mathrm{ml}$. of crude eluate should have produced similar death rates in mice as the above doses of purified preparation when tested under similar conditions. For this, the content of factor I in the crude eluate (which is crude factor I + crude factor III) was estimated (by serological precipitation; see Stanley \& Smith 1961) and adjusted to $4 \mu \mathrm{g} . /$ dose by addition of purified factor I before adding purified factor II (40 $\mu \mathrm{g} . /$ dose) and injecting the mixture into mice. Under these conditions, 0.025 and $0.0125 \mathrm{ml}$. of crude eluate killed $21 / 30$ and 18/30 mice, respectively; these are death rates similar to those produced by the corresponding doses of purified preparation.

The final product was used as prepared (i.e. in $0 \cdot 05 \mu$ phosphate buffer at $\mathrm{pH} 7 \cdot 4$ ) for ultracentrifugal, electrophoretic and serological analyses and for biological tests; for chemical analysis the solution was thoroughly dialysed and freeze-dried. 


\section{Criteria of purity}

Ultracentrifugation. The final preparation showed a single peak in the ultracentrifuge (Fig. 1).

Paper electrophoresis. The final preparation of factor III was concentrated by dialysis against Carbowax. When examined in $0.2 \mu$ barbitone buffer $(\mathrm{pH} 8.6)$ the material ( $0.5 \mathrm{mg}$. dry wt.) migrated, as a single band $(9 \mathrm{~cm}$.; in the system described by Stanley \& Smith 1961), towards the anode. It was not examined at an acid $\mathrm{pH}$ value since the concentrated solution precipitated at $\mathrm{pH} \mathbf{5 \cdot 9}$.

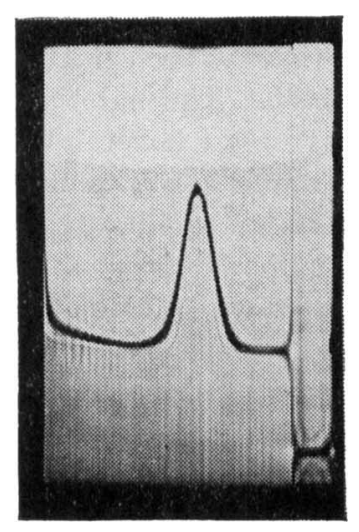

Fig. 1. Ultracentrifuge diagram of the best preparation of factor III $(0 \cdot 85 \%, w / v)$. Sedimentation in $0.05 \mu$ phosphate buffer ( $\mathrm{pH} 7 \cdot 4$ ), field $100,000 \mathrm{~g}$. Picture taken $48 \mathrm{~min}$. after reaching maximum speed. Sedimentation from right to left.

Serological precipitation in gels. Against spore antiserum (H. 533) the final preparation of factor III ( $70 \mu \mathrm{g}$.) formed a strong and a faint line; the latter was due to factor I. Appropriate comparative titration with purified factor I indicated that contamination with this factor was less than $2 \%$. The strong line appeared to be single (and remained so on dilution) and was different from the lines formed by purified factors I and II. However, when certain concentrated fractions containing mixtures of antigens from Bacillus anthracis were diffused side by side with the final preparation of factor III, two of the lines formed by these mixtures joined with the single line from factor III. Furthermore, when concentrated solutions were allowed to diffuse for long periods (23 days), on plates having a long distance between the diffusion wells, two closely associated lines were sometimes apparent. Hence the factor III line might be composite (compare purified factor II; Sargeant et al. 1960). Attempts to separate two possible components by fractionation on DEAEC and on hydroxylapatite, by fractional precipitation with ammonium sulphate and by precipitation at different acid $\mathrm{pH}$ values failed; all the fractions obtained from these procedures showed the same single line on serological diffusion plates. 


\section{Properties}

Chemical analysis. The final preparation of factor III had N 15.1\%; 'protein' (as ovalbumin) $90 \%$; carbohydrate (as glucose) less than $0.5 \%$; P less than $0.05 \%$; lipid less than $1 \%$; sulphated ash, less than $0.2 \%$. Paper chromatography of a hydrolysate $\left(6 \mathrm{~N}-\mathrm{HCl}, 100^{\circ}\right.$, overnight) showed all the usual amino acids and no others. The ultraviolet absorption spectrum was typical of a protein, and showed no evidence for the presence of nucleic acid.

Biological properties. The final preparation of factor III was not lethal for mice when injected ( $60 \mu \mathrm{g}$. per mouse) alone; when added to a mixture of purified factor I ( $4 \mu \mathrm{g}$.$) and factor II (40 \mu \mathrm{g}$.) which alone killed only 10/126 mice, it $(8,4,2 \mu \mathrm{g}$.) produced many mouse deaths $(49 / 66,22 / 28,10 / 20$ respectively $)$. This activity of factor III was not decreased by allowing it to stand for $24 \mathrm{hr}$. at $0^{\circ}, 18^{\circ}$ or $37^{\circ}$. Addition of the final preparation of factor III to mixtures of purified factors I and II decreased the capacity of the latter mixtures to produce oedema in the skin of rabbits. Skin lesions of size 16:60 produced in rabbits by a mixture of factor $\mathrm{I}(1 \cdot 6 \mu \mathrm{g})+$. factor II (16 $\mu$ g.); (compare Table 5, Stanley \& Smith, 1961) were decreased to $7: 23,9: 40$, $11: 50$ by addition of $3 \cdot 2,1 \cdot 6,0 \cdot 8 \mu \mathrm{g}$, respectively, of the best preparation of factor III. In serological diffusion plates $0 \cdot 2 \mu \mathrm{g}$. of the best preparation of factor III still formed a line against spore antiserum (H535). Against antigen antiserum (H 25), high concentrations of factor III formed only a hazy line which easily dispersed in antigen excess, indicating a low content of factor III antibody in this antiserum.

We are indebted to Mr F. C. Belton for producing the anthrax toxin and to Mr R. Blake for excellent technical assistance.

\section{REFERENCES}

Harris-Smith, P. W., Smith, H. \& Keppie, J. (1958). Production in vitro of the toxin of Bacillus anthracis previously recognized in vivo. J. gen. Microbiol. 19, 91.

Sargeant, K., Stanley, J. L. \& Smith, H. (1960). The serological relationship between purified preparations of factors I and II of the anthrax toxin produced in vivo and in vitro. J. gen. Microbiol. 22, 219.

Smith, H., Keppie, J. \& Stanley, J. L. (1955). The chemical basis of the virulence of Bacillus anthracis. V. The specific toxin produced by B. anthracis in vivo. Brit. J. exp. Path. 36, 460.

Smith, H., Tempest, D. W., Stanley, J. L., Harris-Smith, P. W. \& Gallop, R. C. (1956). The chemical basis of the virulence of Bacillus anthracis. VII. Two components of the anthrax toxin; their relationship to known immunizing aggressins. Brit. J. exp. Path. 37, 263.

Stanley, J. L., Sargeant, K. \& Smith, H. (1960). Purification of factors I and II of the anthrax toxin produced in vivo. J. gen. Microbiol. 22, 206.

Stanley, J. L. \& Smith, H. (1961). Purification of factor I and recognition of a third factor of the anthrax toxin. J. gen. Microbiol. 26, 49.

Thorne, C. B., Molnar, D. M. \& Strange, R. E. (1960). Production of toxin in vitro by Bacillus anthracis and its separation into two components. J. Bact. 79, 250. 